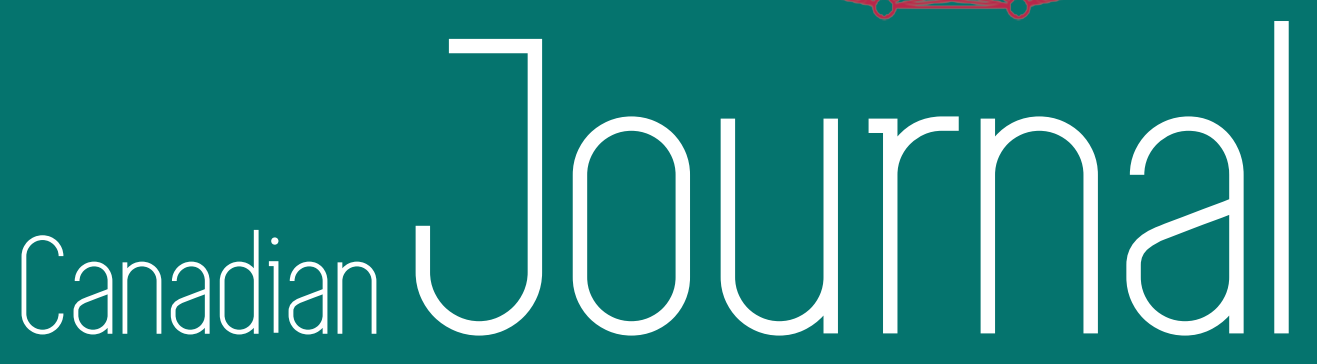
of Mathematics \title{
canadien de
} mathématiques 


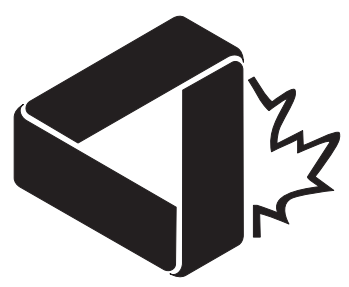

\title{
CANADIAN JOURNAL OF MATHEMATICS
}

\section{JOURNAL CANADIEN DE MATHÉMATIQUES}

\author{
EDITORS-IN-CHIEF / RÉDACTEURS-EN-CHEF \\ Louigi Addario-Berry \& Eyal Goren \\ Department of Mathematics, McGill University \\ cjm-editors@cms.math.ca / jcm-redacteurs@smc.math.ca \\ Associate Editors / RÉDACTEURS AsSOCIÉs
}

Fabrizio Andreatta

Università degli Studi di Milano

Kathrin Bringmann

University of Cologne

Guillaume Chapuy

Université Paris Diderot

Alexander Furman

University of Illinois at Chicago

Vojkan Jakšić

McGill University

Javad Mashreghi

Université Laval

Malabika Pramanik

University of British Columbia

Jianhong Wu

York University
Jason Bell

University of Waterloo

Alex Brudnyi

University of Calgary

Ilijas Farah

York University

Wee Teck Gan

National University of Singapore

Lisa Jeffrey

University of Toronto

Marco Merkli

Memorial University

Alistair Savage

University of Ottawa
Hans Boden

McMaster University

Krzysztof Burdzy

University of Washington

Ailana Fraser

University of British Columbia

Philippe Gille

CNRS et Université Claude Bernard

Erwin Lutwak

Courant Institute

Nilima Nigam

Simon Fraser University

Dani Wise

McGill University

(C) Canadian Mathematical Society / Société mathématique du Canada, 2020

All rights reserved / tous droits réservés

Suite 209, 1725 St. Laurent Blvd., Ottawa, ON K1G 3V4

ISSN 0008-414X (Print / imprimé), 1496-4279 (Online / électronique)

The geometric figure on the cover, a four-dimensional polytope, was redrawn from the inside cover page of the celebrated book 'Regular Polytopes' by Harold Scott MacDonald Coxeter (1907-2003), one of the greatest geometers of the 20th century. Coxeter, a Fellow of the Royal Society of Canada and a Fellow of the Royal Society (London), joined the University of Toronto in 1936 and worked there enthusiastically for 60 years. Since 1978, the Canadian Mathematical Society has awarded the Coxeter-James Prize in his honor.

La figure géométrique sur la couverture, un polytope en dimension quatre, a été reprise du plat intérieur du célèbre ouvrage Regular Polytopes de Harold Scott MacDonald Coxeter (1907-2003), l'un des plus grands géomètres du XXe siècle. Membre de la Société royale du Canada et de la Royal Society (Londres), H.M.S. Coxeter s'est joint au corps professoral de l'Université de Toronto en 1936, où il a travaillé avec enthousiasme pendant 60 ans. Depuis 1978, la Société mathématique du Canada décerne le prix Coxeter-James en son honneur. 